\title{
Monitoring the Peace? : Northern Ireland's 1975 ceasefire incident centres and the politicisation of Sinn Féin.
}

\begin{abstract}
During the Provisional IRA's (PIRA) 1975 ceasefire, two different sets of incident centres were established across Northern Ireland in order to monitor and avert escalation of violence between Republicans and Security Forces. While one group of these offices were run by the Northern Ireland Office (NIO) and administered by clerks in the Northern Ireland Civil Service, very quickly Sinn Féin (taking advantage of their decriminalisation in 1974) established their own incident centres to coordinate their communication with the government. This article argues that the establishment of the Sinn Féin incident centres set a precedent for the future political activity of the Provisional Republican Movement; that their activity during the 1975 ceasefire played an important formative role in the evolution of the group's political strategy; and that this experience, acquired from the work done during the 1975 truce, was of far greater influence than is appreciated in current accounts.
\end{abstract}

The period surrounding the PIRA's 1975 ceasefire has recently become the site of a large amount of new research due in equal measure to the availability of new archive resources ${ }^{1}$ as well as the rich comparisons that can be drawn between this failed ceasefire and the PIRA's later attempts in 1994 and $1996 .^{2}$ The emphasis of the new studies has often been to look in detail at the talks between the British Government and the PIRA leadership and have come to broadly similar conclusions on the following fundamental points: that Prime Minister Harold Wilson managed contact with the IRA in their initial weeks whilst at the same time considering the option of some kind of British 'withdrawal'3 from Northern Ireland; that support for such a withdrawal was the 'majority view' ${ }^{4}$ of much of Wilson's Labour Cabinet but that priorities changed and these talks failed due to pressures on both the IRA ${ }^{5}$ and the British government. ${ }^{6}$ 
The focus of much of this new research, though important in debating both the importance of the ceasefire specifically and the utility of secret backchannel talks more generally, remains narrowly focused around those at the top of both the IRA and the British Government at the time. With the IRA however, the case can be made that such an approach misses the important point that the Provisional IRA were the leading arm of a 'deeply rooted working-class ethno-nationalist movement ${ }^{77}$ and therefore one that still had to be representative in at least some respects of the communities, members and organisers through which they operated. Despite this, accounts of the work of the incident centres has never before been seen as central to the narrative of the 1975 ceasefire and their work is notable for its absence even in accounts of Provisional IRA strategy. This paper seeks to demonstrate that these incident centres gave Sinn Féin and PIRA activists practical political and representative experience for the first time, particularly in Belfast and Derry and that this experience occurred at a level far below that of the Army Council and their talks via the 'Derry Link' with the British. It was also different in form from the largely theoretical debates that occurred in this time within the prisons. Thus this article demonstrates that while the incident centres were of frustratingly limited use for much of the ceasefire, their function and form set a precedent for Provisional Sinn Féin's later political organisation, whether that be in the organisation of support for the 1981 Hunger Strikes, in the later election of its representatives, in the arrangement of community justice and punishment attacks, or in the later support of the peace process. This article argues that the Sinn Féin incident centres were the functional antecedents of the Sinn Féin Offices that became prominent in Northern Ireland's towns and cities from the 1980s and thus are the direct ancestors of the 'Armalite and Ballot Box' strategy of the 1980s in a way that has not yet been fully appreciated.

Although the above may sound a fairly simple and logical historical observation to make, it is one that is important as it contradicts the widely accepted narrative of the development of Provisional Sinn Féin, and, ultimately, the origins of the Peace Process. This narrative has a tendency to focus around the personalities of Gerry Adams, Danny Morrison and Martin McGuinness, whose 
political careers - they have insisted - were dependent on their opposition to the 1975 ceasefire (or at least, to its outcomes). Presented by a diverse range of academics and journalists from Peter Taylor to David McKitterick and Eamonn Mallie; and from Ed Moloney to MLR Smith this narrative is united on the following points:

1. The 1975 truce was a disaster for the Provisional movement. ${ }^{8}$

2. The PIRA Army Council had been fooled into calling a ceasefire that was designed to erode their military capacity by inertia..$^{9}$

3. It allowed for the ending of 'Special Category Status' for paramilitary prisoners without serious protests from republicans. ${ }^{10}$

4. It led to the later acceptance of a no-ceasefire stance to which Martin McGuinness and Gerry Adams were central. ${ }^{11}$

5. It led directly to the new predominance of PIRA Northern Command and the ousting of prominent Southerners from both Sinn Féin and the PIRA Army Council. ${ }^{12}$

Such rare historiographical agreement between a diverse range of respected research regarding the emergence of the new and northern Sinn Féin in the 1980s has undoubtedly made an impact on how the Republican movement is studied whether historically, or contemporaneously. This is epitomised in the weight given to the role of Adams and McGuinness in the 1990s in bringing (and keeping) the Republican movement at talks and in government. This narrative's immutability is demonstrated most clearly in Martyn Frampton's recent book The Long March where Frampton argues clearly albeit with one specific reservation - that his work on the movement's '[representative] political' strategy begins at the moment that strategy became conspicuous, in 1981. Therefore, while Frampton considers the 1975 ceasefire as a potential starting point for his study on Sinn Féin's political strategy, he quickly comes to the conclusion that 'it was only in the aftermath of the hunger strike that the movement began to view 'politics' as a serious project. ${ }^{13}$ Andrew Sanders' recent work also serves to highlight the perception that the PIRA after 1976 made a clean break with that which had come before, in doing so excluding the possibility of continuity of policy and describing 
the 1975 ceasefire as 'the split that never was. ${ }^{14}$ MLR Smith states similarly that prior to the 1981 Hunger Strike the Provisional Movement had no political interests whatsoever and that their reliance on a purely anti-colonial platform 'provided them with an argument to legitimise their campaign of violence free from any political dimension because in their view there could not, literally, be any politics so long as the colonial relationship lasted. ${ }^{\prime 15}$ Frampton, Sanders and MLR Smith's analyses accept the received logic by glossing over Sinn Féin's actions prior to the Hunger Strike and ignoring the potential for influence from the period of the 1975 truce. Doing this, serves to place Gerry Adams and his cohort of so-called 'Young Turks' very much at the centre and as the originators of policy within the Provisional Republican Movement, but only after they had risen through the ranks unblemished by experience of the anomalous 1975 truce.

The emergence of this standard narrative has not gone unnoticed. Richard English warned in 2003 that 'the conspicuously political emphasis of the republican movement in the mid-1990s has sometimes caused observers, in contrast, to underplay the degree to which earlier Provisionalism had a political energy and content to it.... It was always political when it thought it expedient and sensible to be so. ${ }^{16}$ The assumptions made above have been most recently examined by Robert White who argues that the Provisional IRA's leadership was not, in fact, overrepresented by southerners, that they were not tricked into negotiations by the British, that they did not slip into sectarianism due to a lack of leadership in 1975, and that in fact the Provisional IRA was 'not significantly harmed by the truce ${ }^{\prime 17}$ despite what later republican leaders said. ${ }^{18}$

White's intervention can be extended further. This article argues that the later advancement of Sinn Féin (and northern Sinn Féin at that) was aided by experience of political organisation prior to the arrival of the Adams/McGuinness leadership and that to date the politicisation of Sinn Féin to the 1980/81 Hunger Strikes is to disregard the experience gained by a significant number of the Provisional Movement's activists during the 1975 truce. Kacper Rekawek has recently noted that in the 1980s the movement to the Armalite and Ballot Box strategy required the Republican Movement to increase the number (and influence) of non-military activists within its organisation. ${ }^{19}$ In a sense, 
the incident centres of 1975 are the first example of the Provisionals moving in this direction, acquiring these skills and politicising themselves.

Incident Centres were established in 1975 as a direct result of how the PIRA's previous 1972 ceasefire negotiation structures had been established and because of the manner in which that ceasefire had broken down. MI6's Frank Steele, on secondment to Northern Ireland since 1971, became advisor to the newly appointed Secretary of State William Whitelaw in March 1972. Steele had already been in contact with Dáithí Ó Conaill - then presumed Chief of Staff of the Provisional IRA - via a number of different intermediaries since February $1972 .{ }^{20}$ Through John Hume and the SDLP, Steel attended face to face discussions in Derry that culminated in a ceasefire and a secret visit to London by a PIRA delegation in July. These talks included, both Martin McGuinness and Gerry Adams (who had been specifically released so that he could participate) and in the course of these talks it was agreed that a so-called 'incident hotline' would be established at Laneside, the building used for discreet talks between a whole range of government officials and political, religious, community and paramilitary figures throughout this period. This hotline was basically the office telephone number, with a messaging service for when Frank Steele was elsewhere. ${ }^{21}$

While he may have been in charge of the talks, Steele did not have control over the security forces in Northern Ireland and the fact that security was being handled by a different section of the NIO proved problematic when issues and misunderstandings arose as a result of using the hotline. The fact that anyone could telephone Steele for any reason was also problematic. Only days after the fractious Cheyne Walk meeting in London for example, Ó Conaill used the hotline to talk to Steele about his worries over the British Army's resistance to the occupation of vacant homes in the Lenadoon area of West Belfast by homeless Catholic families. Ó Conaill was concerned that the local Belfast commander Seamus Twomey would bring his men into conflict with the British Army over the issue but Steele refused to act. ${ }^{22}$ Later, Steele received another phone call which he thought was from Twomey. ${ }^{23}$ According to Peter Taylor - based on an interview with Frank Steele: 
'Because of the IRA attitude at the London meeting, Steele was determined that the IRA should not think that HMG would do anything just to preserve the ceasefire, and was therefore deliberately laid-back about the escalating crisis in Lenadoon Avenue. When... O'Connell said the ceasefire was breaking down, Steele said it was a pity, but he hoped to see O'Connell again soon. ${ }^{24}$

Steele did not step in to resolve the crisis that eventually broke the 1972 ceasefire - the Lenadoon affair - nor could he have stopped the shooting of a further five Catholic civilians (including a 13 year old girl and a priest) by British soldiers five miles away in Ballymurphy. ${ }^{25}$ The hotline between negotiators was ill-equipped to deal with the minutiae of contentious incidents on the ground when the same channels were being used to discuss the broader political problem itself. It was accepted by all parties that future ceasefires would need a systematic incident reporting and aversion scheme.

Seamus Loughran, although interned shortly after the Lenadoon affair, had been one of Steele's initial contacts with the IRA. Once released in 1974, Loughran returned to a public role within Sinn Féin (and a private one on the PIRA Army Council ${ }^{26}$ ) and soon made contact once more with Laneside. Steele's two successors, Michael Oatley and James Allan spoke with Loughran fairly regularly in the summer of 1974 as Sinn Féin's Belfast spokesman. Although initially Loughran emphasised his concern about prison conditions, he also spoke of how previously he had felt that the officials at Laneside had 'looked down on me as if I was something that had crawled out of a bog.' A position that was radically different by July $1974 .{ }^{27}$ Following the Sunningdale agreement of December 1973 which established a power sharing executive between Northern Ireland's main political parties, the role of Laneside had expanded significantly and with the Secretary of State's decriminalisation of both the UVF and Sinn Féin in April 1974, the representatives of these two groups were free to speak to Laneside officials beyond those working for MI6 and without the need for pseudonyms. ${ }^{28}$ Certainly this was in part due to the NIO's desire (under the leadership of their highly regarded Permanent Secretary Frank Cooper) to engage with and in so doing attempt to 
crystallise the extreme paramilitary groups in Northern Ireland around more conventional forms of party politics. This tactic may not have achieved instantaneous success with either the UVF or the PIRA though it arguably created empathy between the paramilitary representatives and the British officials they were dealing with, and this was hugely important to the way in which the 1975 ceasefire was later handled.

By the autumn of 1974 however there were too many potential Republican backchannels coming forward. These usually well-meaning individuals were complicating and diluting the messages being transmitted between the two sides. To complicate matters further, talks at Laneside were publicised in detail by the New Statesman in November ${ }^{29}$ and the names of the British Officials leading the talks were leaked by Robert Fisk in The Times in January. ${ }^{30}$

When a first ceasefire, arranged to be an extension of the Christmas ceasefire of 1974/5, collapsed in the middle of January, both the PIRA and the British primarily blamed the amount of contradictory information being passed through the numerous political backchannels for their numerous misunderstandings. There is some evidence to suggest that both the Secretary of State and the IRA specifically held Seamus Loughran's to blame in this regard. ${ }^{31}$ Loughran had given an unauthorised submission to the government's Gardiner Commission in which he gone far beyond the IRA leadership's stated position had embracing the potential end of internment (and with it, Special Category Status) for paramilitary prisoners. ${ }^{32}$ Possibly for his own safety, Loughran went to New York on a fundraising trip during the crucial weeks between the two ceasefires (his visa was unopposed by the NIO, and the Secretary of State even commented in his diary 'Loughran... made such a mess of it that I think he is lucky not to have been shot by the Prov. IRA and he has gone off to America' $\left.{ }^{\prime 3}\right)$. On his return, Loughran was dropped from the PIRA Army Council. Thus, by the time the ceasefire was arranged, the backchannel contacts were discreetly reduced from around half a dozen to really only one which mattered, and one which didn't, the secret Derry Link between Brendan Duddy and the PIRA Army Council was maintained, and the occasional Laneside chat with the Belfast Provisionals that was maintained through Billy McKee and Jimmy Drumm. 
Of the other links, those with Conciliation Ireland, Rev. Arlow and even Dáithí Ó Conaill's personal link through $\mathrm{Dr}$ John $\mathrm{O}^{\prime}$ Connell were dropped at this time, ${ }^{34}$ and Rees made a statement in which he outlined why any future would more suitable structures for communication,

'Many ill founded rumours are circulating. There is much speculation. There is a real need to distinguish fact from fiction and those who report have a particular responsibility at this time to avoid turning speculation into expectation.' ${ }^{35}$

Rees outlined his approach to the House of Commons on 11 February 1975:

'...my officials put to Provisional Sinn Féin a scheme designed to make effective arrangements for ensuring that any future cease-fire did not break down.

'This has five main elements. First, a number of incident centres, manned by civil servants on a 24-hour basis, will be established in various parts of Northern Ireland. These centres will be linked with my office in Belfast. Second, if developments occur which seem to threaten the cease-fire, these incident centres will act as a point of contact in either direction. Third, issues can be referred to my office in Belfast and clarified there. Fourth, cases referred up to the Northern Ireland Office will be considered, and a reply passed back to the incident centre for onward transmission. Fifth, if out of these exchanges general difficulties about the cease-fire arrangements emerge, then discussions will be arranged between my officials and representatives of legal organisations to clarify them.' $^{36}$

In response, the IRA re-sent Rees a list of 12 points that would be the basis of the new truce. The document included in point 9, 'Agreement on an effective liaison system between British/Republican forces. ${ }^{37}$ 
The political context in which the PIRA ceasefire was negotiated should also not be forgotten. The British were working on two initiatives by the end of 1974, both with the intention of creating political stability in Northern Ireland whether that be through an enhanced criminal justice response to terrorist crimes, or the establishment of democratic structures that would seek agreement on the province's governance. As already stated, the Gardiner Report into the imprisonment of paramilitaries was making inquiries into the procedures for the detention of terrorists in Northern Ireland at this stage, and reported back in early 1975 recommending the ending of internment without trial and the 'criminalisation' of terrorist offences in a process that would eventually lead to the ending of special category status for paramilitaries in prisons. The Constitutional Convention - a series of talks aimed at restarting a power sharing executive between the main political parties - continued, winding their way toward acrimonious collapse in March $1976 .{ }^{38}$ With this in mind, the regular secret meetings with Michael Oatley, James Allen and later Donald Middleton in Derry amounted only to a part of a ceasefire within a broader political process that was almost continuously stalling. However, with the incident centres this theoretical/political side of the ceasefire could continue so long as both sides wanted to meet and in fact continued long after the ceasefire itself was being kept in any meaningful way. The incident centres would ensure there would be no crossed wires, no repeat of the intransigence of Lenadoon, and that potential sore points would be dealt with before they were tabled at the leadership meetings in Derry. The ceasefire itself, it was hoped, would give enhance the stability of the otherwise unrelated Constitutional Convention talks taking place elsewhere.

Thus, on 15 February 1975, with the ceasefire reinstated, the NIO established 6 government incident centres staffed by Department of Health and Social Services (DHSS) clerks and located in Belfast, Newry, Armagh, Dungannon, Derry and Enniskillen. Initially secret, the centres (codenamed TOWERs) transmitted their messages to Stormont Castle, via a teleprinter system known as RAMPART. The government incident centres were meant to be individual 
links between specific known members of Sinn Féin. However, when Sinn Féin established their own incident centres, the government offices became the clearing houses for much larger numbers of complaints about Security Force activity than had been anticipated.

Fig 1. PIRA 1975 Truce talks: the Incident Centre arrangement. $n$ the British and the Provisionals during the 1975 ceasefire were arranged. The incident centres effectively isolated those involved in the conflict from those involved in the talks, in turn creating a closed loop of exclusively northern republican activists corresponding with the NIO exclusively through the incident centres. There was thus a profound gulf between what the leadership of the Provisional Movement experienced in this period and what those on the street saw and did.

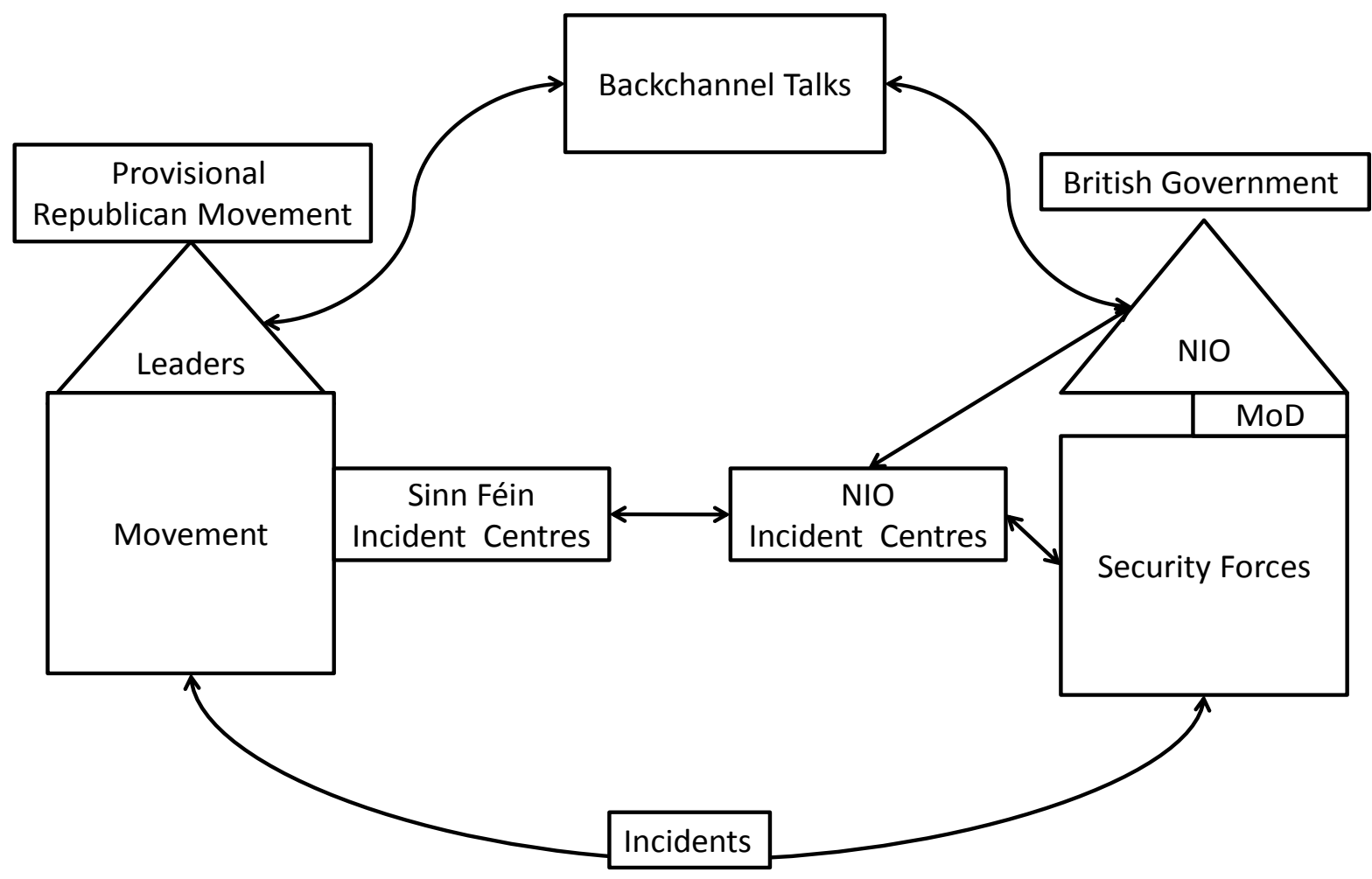

In total, almost 1,000 complaints were made during the ceasefire by low-level Sinn Féin organisers and representatives stationed at their own incident centres regarding Security Force harassment. The Security Forces in turn used system around 400 times to complain 
about republican activity. ${ }^{39} \mathrm{~A}$ later breakdown of how they were used demonstrates the varied concerns of Sinn Féin on the ground in 1975. 
Fig 2. Combined figures for incidents reported February to October 1975

\begin{tabular}{|l|r|}
\hline Type of Complaint & Frequency \\
\hline Unacceptable Security Force [SF] patrolling & 129 \\
\hline General SF Harassment & 258 \\
\hline Arrests & 251 \\
\hline Searches & 100 \\
\hline SF Photographing, VCPs, Misc. & 175 \\
\hline Harassment of PSF Incident Centres & 54 \\
\hline Total & $967^{40}$ \\
\hline
\end{tabular}

The Sinn Féin incident centres were established in key locations inside Catholic neighbourhoods. There, the offices were staffed by local activists and the centres followed the long established Republican tradition of self-reliance and self governance, at a time when Sinn Féin members, due to the policy of abstentionism, had no experience of elected political office and very limited amounts of community representation or advocacy. Their work within this incident centre reporting system gave many of them their first taste of local political organisation and engagement.

The Sinn Féin centres had not been part of any agreement with the British as such; and while their shared names caused some confusion, these centres opened their doors to their communities and, just as importantly, to the press during the 1975 ceasefire. In February, BBC Radio Ulster reported on this development in an interview with an unnamed Sinn Féin representative who gave an important perspective on the role of these centres:

'We are here to take complaints of any nature at all concerning the people in this estate. Complaints regarding the activities of the RUC. Activities of the British Army and harassment. Also incidents which happen to people 
smashing windows, kids, acts of vandalism, people stealing cars and things like that... We are not acting as a police force, we are acting as a community service... we reject the RUC... [we] take action ourselves. Usually it means coming along and talking to the people concerned. If there is a robbery we try and get the money back. ${ }^{41}$

Although the interviewee dismissed the idea of passing on complaints to the police they did admit that they would phone 'HQ in Lower Falls' who they believed 'are in contact with the British Army Authorities' should a breach of the ceasefire occur. ${ }^{42}$

The Irish Times along with all the other major newspapers began covering stories that emanated from these centres on almost a daily basis. The centres gave journalists a location from where their questions could be answered and they no longer had to rely on their secretive and clandestine contacts or the less well-informed Dublin offices. Those who ran the incident centres included prominent northerners like Jimmy Drumm who ran the Falls Road incident centre/Sinn Féin Office and was cited on at least seventeen occasions by the Irish Times during the truce. ${ }^{43}$ The centres gave credence, responsibility and a degree of respectability to those who had previously been living the covert lives of illegal guerrillas. But also, what is clear from press interactions with the Sinn Féin incident centres is a sense that those who staffed them felt they had a responsibility to reflect community feeling rather than impose it. The BBC Radio Ulster journalist elicited the telling quote, 'We in Sinn Féin, representing the people in this area, can only do what the people ask.' ${ }^{44}$

In Derry, the incident centres' role in reporting breaches of the truce quickly became neglected. It was replaced instead by a new role of community restorative justice. Though socalled punishment attacks on those committing anti-social behaviour were nothing new, the incident centres allowed Sinn Féin to go after new and different targets. In September 1975 for example the IRA seized alcohol from publicans accused of selling to under-age youths. The 
plunder was put on display for both locals and the media 'at the ceasefire incident centres in Bogside' and those publicans from whom the alcohol had been seized were told they could only get in back by guaranteeing not to serve alcohol in future to the under-age youths. ${ }^{45}$

The Security Forces in general - as was noted in numerous summaries of complaints took a dim view of the development of the incident centres ${ }^{46}$ and almost immediately began surveillance against them, questioning those who frequented them and occasionally entering the offices to search them. ${ }^{47}$ This was especially true of the $2^{\text {nd }}$ Battalion of the Parachute Regiment (2Para), that summer stationed in West Belfast. 2Para, it was alleged, entered, searched and removed papers from the offices on several occasions in broad daylight. This caused incidents to be reported down the line as breaches of the truce, to the NIO. It is apparent from the documents recently released that the NIO's relationship with the Ministry of Defence over this matter was strained ${ }^{48}$ not least because battalion commanders in Northern Ireland had been urged to slow-pedal in Nationalist areas since the end of $1974 .{ }^{49} \mathrm{By}$ the summer, it seems, Sinn Féin incident centres had become too important for the military to ignore when violence was reinstating itself as the primary means of communication between the PIRA and the Security Forces. The NIO regularly explained the problems to the MOD and clearly told them that 'the Centres are the offices of a political party and are sensitive because of the part they play in incident reporting. They should therefore not be "harassed" 50 but when the NIO asked that troops be sent using a 'horses for courses' system, the MOD's reply was 'predictable but disappointing'. ${ }^{51}$

The public face of the Sinn Féin Incident Centres also caused great suspicion among loyalist groups who had not reciprocated in 1975 by calling their own ceasefire. The UDA's Andy Tyrie got in touch with James Allan at Laneside, visiting him there on the evening of 26 February 1975 . This led to two further meetings the following day where the UDA delegation met with Frank Cooper and subsequently the Secretary of State. Their concern was that the opening of incident centres would lead to the emergence of IRA-style police forces in Catholic areas. They had not anticipated an IRA 
ceasefire at all, and the implications of one made them nervous. The loyalists suspected the IRA had made a secret deal with the British 'otherwise the present ceasefire could not be explained. ${ }^{52}$

Frank Cooper tried his best to allay the UDA's fears of any sell out, 'Provisional Sinn Fein' he told them, 'had exploited the situation cleverly. They had mounted a powerful propaganda effort which appeared to have taken in many people (including, by implication, the UDA) ... [but that surely] it was better that they expend their energies in a political way than in terrorism. ${ }^{53}$ Allan, Cooper and Rees failed in their attempts to allay the UDA's fears and upon leaving these meetings Tyrie announced that they intended to police loyalist areas themselves from the following evening. ${ }^{54}$

In early 1975, division within the various loyalist groups meant that the UDA were bluffing. When compared to the similar meetings the UDA leadership had had at the height of the UWC disturbances the previous year ${ }^{55}$ far fewer now responded to the UDA call and their initiative thus lacked local support and quickly fizzled out. When the UDA held another meeting with Rees the following day, Tyrie backed down and changed his tone, making the excuse that 'the atmosphere had been so pleasant [this time] that he had not found an opportunity to shout. ${ }^{15657}$

Despite the urgent assurances of the Secretary of State, the IRA ceasefire - which was pockmarked throughout by very serious instances of violence - was met by an increased loyalist paramilitary campaign which included some of these groups' most harrowing atrocities of the Troubles. ${ }^{58}$

Loyalist violence erupted with greater ferocity than ever in 1975.The IRA's response to this loyalist upsurge was often equally as sectarian by the autumn of 1975 . This, along with the continued OIRA/PIRA feud meant that more people died in the Troubles in 1975 than in 1974 and as a result, the government incident centres were finally closed on 12 November 1975 following a message from RAMPART that advised the TOWER centres to 'Make no further attempt to telephone your contact. If you are yourself contacted please say "This incident 
centre is closed"... After 5pm you may stand down and it will not be necessary to man your centre overnight. ${ }^{59}$

Within the IRA itself the work of the incident centres became seen as a farce by more than the hawks alone. Jimmy Drumm told the Irish Times on 13 November that 'the incident centres had outlived their usefulness. ${ }^{\prime 60}$ Seamus Loughran echoed Drumm and the Irish Times noted that, '[Loughran] said last night that they would be no loss, 'for all the use they have been during recent times. ${ }^{61}$ The PIRA in Derry however had already made their feelings on this point known, having blown up their own office on 10 November. ${ }^{62}$

Such was the ignominious nature of the long descent back into violence, the IRA have ever since referred to this period as the darkest in the most recent Troubles. They have argued that fighting loyalists and each other distracted them from whom their real fight was with. Certainly their political agenda did not countenance many of the atrocities committed by the PIRA in the autumn of 1975, these included continued bomb attacks in Britain, and the sectarian murder of Protestants such as at Newtownhamilton's Orange Hall on 1 September $1975 .{ }^{63}$ However the argument that the Provisional Movement's own hawks - often referred to simply as 'northerners' - emerged with a new strategy under the leadership of Adams and McGuinness following the opportunities presented to it by the Hunger Strikes ${ }^{64}$ is a flawed over-simplification. The perception of Belfast Republicans at the time was made in an official statement a few days after the closure of the government centres and indicates a consciousness already within the IRA that the ceasefire was part of Britain's attempt 'to 'politicise' the struggle.' This statement added however that 'Sinn Féin advice centres would remain open, including the main centre on Belfast's Falls Road', indicating clearly that there was not to be a complete rejection of the practice of open politics. ${ }^{65}$

In fact the story of the 1975 truce, seen from the perspective of the incident centres is almost entirely a story of Northerners, and hawks at that. From Billy McKee, to the staff of the 
Incident Centres including Jimmy Drumm ${ }^{66}$ and Seamus McCusker ${ }^{67}$, these were men who had spent the previous five years engaged in some of the most horrendous fighting Irish Republicans had ever known. They had been interned and beaten, had killed and been killed in the name of the same goal as their successors. The army council contained numerous Northerners too at this time, all of whom were closely involved in the talks, even if those talks were never going to achieve their stated aim.

The Sinn Féin Incident Centres were essential to the 1975 ceasefire and furthermore gave the Provisional Movement a public face that it had not shown before. Although the vigilante element of this was never welcomed by the NIO, the offices that remained allowed Sinn Féin to become more visibly active in their communities than before. In the NIO's words Sinn Féin was clearly 'politicising' itself, and this was cautiously welcomed. ${ }^{68}$ To accept this conclusion one does not need to rule out the importance of Adams, Morrison and McGuinness later in the 1980s and 1990s, but it does highlight the fact that as a movement, the Provisionals were larger than these three figures and that they were altered by the historical precedent of these incident centres, in a way that many accounts have ignored. In fact, the incident centres mark the first foray into political representation for the Provisional Republican Movement, and marked out the pattern for the future communal and political practices of Provisional Sinn Féin.

In 1977, Jimmy Drumm gave the Provisional Movement's Wolfe Tone commemoration address at Bodenstown cemetery. In what is widely regarded as the moment that 'Northern Command' gained ascendancy over the movement, Drumm concluded that:

'we need to make a stand on economic issues and on the everyday struggles of people... an irrepressible mass movement will ensure mass support for the continuing armed struggle in the north. ${ }^{69}$ 
This speech, written by the future Sinn Féin President Gerry Adams, explicitly links the

movement's interests with those of the communities within which they operated. It implies a responsibility to represent their wider interests despite its continued irredentism and commitment to armed conflict. The rejection of the previous leadership's policies of ceasefirethen-negotiate therefore did not mean the rejection of that strategy's offspring in the form of local Sinn Féin offices. From the incident centres, Sinn Féin had acquired the embryo of its later existence as a more conventional political party, albeit one which would continue to reject the authority of the institutions of the Northern Ireland state for some time to come.

\footnotetext{
${ }^{1}$ Archives that include the personal papers of Secretary of State Merlyn Rees at LSE, and the papers of the intermediary Brendan Duddy and Sinn Féin President Ruairí Ó Brádaigh now available at NUI Galway.

${ }^{2}$ Michael Kerr, The Destructors: The story of Northern Ireland's lost peace process (Dublin: Irish Academic Press, 2011), John Bew, Martyn Frampton and Inigo Gurrachaga, Talking to Terrorists: Making peace in Northern Ireland and the Basque Country (London: Hurst, 2009) and Niall Ó Dochartaigh, "IRA Ceasefire 1975: a missed opportunity for peace?", Field Day Review 7 (2011): 50-77.

${ }^{3}$ Although, 'even in its strongest form... withdrawal was never synonymous with Irish reunification' Ó Dochartaigh, "IRA Ceasefire 1975", 58.

${ }^{4}$ Kerr, 296.

${ }^{5}$ Bew et al, 56.

6 Marc Mulholland, "Irish Republican Politics and Violence before the Peace Process, 1968-1994", European Review of History 14, no. 3 (2007), 406 and Ó Dochartaigh, 40.

${ }^{7}$ Mulholland, 397.

8 Patrick Bishop and Eamonn Mallie, Provisional IRA (London: Corgi, 1988), 275 and MLR Smith, Fighting for Ireland? The military strategy of the Irish Republican movement (Routledge: London, 1994), 144.

${ }^{9}$ Ed Moloney, A Secret History of the IRA ( $2^{\text {nd }}$ ed.) (London: Penguin, 2007), 144 and Peter Taylor, Provos: The IRA and Sinn Fein (London: Bloomsbury, 1998), 197.

${ }_{10}$ Moloney, 145, Richard English, Armed Struggle: A secret history of IRA (London: Macmillan, 2004), 188-9 and Henry Patterson, The Politics of Illusion: A political history of the IRA $2^{\text {nd }}$ ed. (Serif: London, 1997), 182.

11 Taylor, 197.

12 Eamonn Mallie and David McKiterrick, The Fight for Peace: The Secret Story Behind the Irish Peace Process (London: Heinemann, 1996); 11-12 and Taylor, 213.

${ }^{13}$ Martin Frampton, The Long March: The political strategy of Sinn Féin, 1981-2007 (London: Palgrave Macmillan, 2009), 11.

${ }^{14}$ Andrew Sanders, Inside the IRA: Dissident republicans and the war for legitimacy (Edinburgh: University Press, 2012), 55.

${ }^{15}$ MLR Smith, 142.

${ }^{16}$ English, 180.

${ }^{17}$ Robert White, “The 1975 British-Provisional IRA Truce in Perspective," Éire-Ireland 45, no.3\&4 (2010), 233.

${ }^{18}$ An example of this is Martin McGuinness' speech to the Sinn Féin Ard Fheis on 2 November 1986 in which he stated, 'the former leadership of this movement has never been able to come to terms with this leadership's
} 
criticism of the disgraceful attitude adopted by them during the disastrous 18 months ceasefire in the mid1970s.' Speech reproduced by University of Ulster CAIN project, http://cain.ulst.ac.uk/issues/politics/docs/sf/mmcg021186.htm

${ }^{19}$ Kacper Rekawek, Irish Republican Terrorism and Politics: A comparative study of the Official and the Provisional IRA (Abingdon: Routledge 2011), 98.

${ }^{20}$ Tony Craig, "From Backdoors and Back Lanes to Backchannels: Reappraising British Talks with the Provisional IRA, 1970-74," Contemporary British History, 26, no 1 (2012), 104.

${ }^{21}$ UK National Archives (TNA:PRO) PREM 15/1009, Telephone Call from Sebastian Coffey, 21 June 1972 and CJ 4/1456, 'The IRA Truce' Top Secret note (Unsigned/undated) c. Sept. 1975, section 12, which states that Ó Conaill used this alias 'Sebastian Coffey'.

${ }^{22}$ Taylor, 145.

${ }^{23}$ Ibid.

${ }^{24}$ Ibid.

${ }^{25}$ Ibid.

${ }^{26}$ Moloney, 143

27 TNA: PRO, FCO 87/342, James Allan, 'Note for the Record: Mr Seamus Loughran', 18 July 1974.

28 TNA:PRO, CJ 4/862, A Huckle (NIO) to Secretary of State, regarding telephone call from Ruairí Ó Brádaigh, 16 April 1974.

${ }^{29}$ Royston Dickson, “Mr Rees's Decolonising Mandarins,” New Statesman, 14 November 1975, 604-5.

${ }^{30}$ Robert Fisk, 'Hopes of new Ulster ceasefire after secret talks with Provisionals' The Times, 20 January 1975.

${ }^{31}$ On Loughran and Belfast's Incestuous Gossip, London School of Economics Archive (LSE) Papers of Merlyn

Rees 1/4, 6. - This section was deleted from Rees' later autobiography.

${ }^{32}$ Robert Fisk, "Why Mr Loughran went to New York," The Times 29 January 1975.

33 LSE Rees, 1/6 Rees Diary c. January 1975; 4. It was noted that Michael Oatley supported Loughran's visa application to the United States. PRO:TNA, CJ 4/863, Allan to Bourn, 13 February 1975.

${ }^{34}$ Idid, 10-11.

35 Ibid, 6.

${ }^{36}$ Merlyn Rees, 11 February 1975, House of Commons Debates, 11 February 1975, vol. 886 c.208.

37 TNA:PRO, PREM 19/521 Undated page marked 'Top Secret: UK Eyes A, Terms for Bi-Lateral Truce' Identical text of which appears in document in the Ruairí Ó Brádaigh papers, facsimile dated 20 January 1975 published in Robert White, Ruairí Ó Brádaigh: The Life and Politics of an Irish Revolutionary (Bloomington, IN: University Press, 2006), 230.

${ }^{38}$ Kerr, 326.

${ }^{39}$ TNA: PRO, CJ 4/867, Incident Centres brief, PTE England to Merlyn Rees, 10 October 1975.

$40 \mathrm{lbid}$.

${ }^{41}$ PRO:TNA CJ 4/861, Transcript from BBC Radio Ulster, 'Good Morning Ulster', 25 February 1975.

$42 \mathrm{lbid}$.

${ }^{43}$ Estimate through study of articles in Irish Times between December 1974 and November 1975 using

ProQuest Historical Newspapers (online newspaper archive).

${ }^{44}$ Admittedly this quote ends, '... And that is to lead them in their fight against the RUC.' but the quote remains pertinent. PRO:TNA CJ 4/861, 'Transcript from Good Morning Ulster' 25 February 1975.

45 "IRA seized liquor in Derry pubs", Irish Times, 22 September, 1975.

46 TNA CJ 4/867, 'The RUC are very unhappy' Wyatt to England, 25 February 1975.

47 "Provisionals admit attack on British Army unit," Irish Times, 23 April 1975 and "Provisionals claim tape taken from soldier has data on Republicans," Irish Times, 24 April 1975.

48 PRO:TNA CJ 4/867 England to Cooper, 1 September 1975 citing reported incidents nos. 1178, 1180 \& 1183.

${ }^{49}$ Kerr, 284-285 and Ó Dochartaigh, 66.

50 Ibid.

51 Ibid.

52 TNA:PRO, CJ 4/838, Meeting between Frank Cooper, James Allan and a UDA delegation, 27 February 1975.

53 Ibid.

54 "UDA decides to police 'loyalist' areas of Belfast," The Times, 28 February 1975.

55 TNA:PRO, CJ 4/2399, 'Meeting between the Secretary of State and the Ulster Loyalist Central Coordinating Committee', Stormont Castle, 28 February 1975.

${ }^{56} \mathrm{lbid}$. 
57 "UDA backs down on private policing plan," The Times, 1 March 1975. - policing plan had been called off the previous day.

${ }^{58}$ For the year 1975, loyalist paramilitaries were responsible for the deaths of 121, in the same period republicans killed 125 . A particularly vicious and sectarian killing spree targeting pubs from July accounts for the majority of these deaths and led directly to the re-proscription of the UVF by Merlyn Rees on 3 October. 59 TNA:PRO CJ 4/867, 'Message from RAMPART to all TOWER centres' 12 November 1975.

60 "Truce in Doubt as Rees closes centres," Irish Times, 13 November 1975.

61 "Back to Base," Irish Times, 13 November 1975.

62 Taylor, 196 also CAIN Chronology of 1975, http://cain.ulst.ac.uk/othelem/chron/ch75.htm\#Nov

63 Moloney, 146-147.

${ }^{64}$ Mallie and McKittrick, 20-22.

65 “Rees decoy failed, say Provisionals," Irish Times, 17 November 1975.

${ }^{66}$ Moloney, 151.

${ }^{67}$ McCusker ran the New Lodge incident centre and was murdered by the Official IRA on 31 October 1975.

68 TNA: PRO, CJ 4/867, DJ Wyatt to PTE England, 25 February 1975; '...it can be regarded by us as the politicization of Sinn Fein which we are anxious to see. This role would therefore be acceptable if it were not for (b) [i.e. vigilantism] above.'

69 Patterson, 180-181. 